\title{
Vertical and horizontal distribution of the microcystin producer Planktothrix rubescens (Cyanobacteria) in a small perialpine reservoir
}

\author{
Adriano Boscaini,${ }^{1 *}$ Flavia Brescancin, ${ }^{1}$ Leonardo Cerasino, ${ }^{1}$ Chiara Fedrigotti,${ }^{1,2}$ Elisa Anna Fano, ${ }^{2}$ Nico Salmaso ${ }^{1 *}$ \\ ${ }^{1}$ IASMA Research and Innovation Centre, Istituto Agrario di S. Michele all'Adige - Fondazione E. Mach, Via E. Mach 1, 38010 S. Michele \\ all'Adige (TN); ${ }^{2}$ Department of Life Sciences and Biotechnology, University of Ferrara, Via Luigi Borsari 46, 44121 Ferrara, Italy \\ *Corresponding authors: adriano.boscaini@fmach.it, nico.salmaso@fmach.it
}

\begin{abstract}
Among cyanobacteria, Planktothrix rubescens (De Candolle ex Gomont) Anagnostidis \& Komárek is a species that is well adapted to develop in moderately nutrient rich and deep lakes. In this typology of waterbodies, the competitive abilities of this species rely in its capacity to stand and growth in the dimly illuminated metalimnetic layer during the warmer months. In this work, we have studied the seasonal development and distribution of this species in Lake Ledro, a meso-oligotrophic reservoir located in the Eastern Alps. During the last decade, this species has given rise to numerous and extended surface bloom episodes, causing the reddening of vast areas of the lake. In summer, the light intensities in the zone of greater development of this cyanobacterium (the metalimnion, between the euphotic depth and the layer of maximum development of the species) were between 2 and $20 \mu \mathrm{mol} \mathrm{m}^{-2} \mathrm{~s}^{-1}$, i.e. values that were well within the light intensities required to sustain the optimal growth of filaments. The formation of the autumn and winter blooms was triggered by the cooling of surface waters and the deepening of the mixed layer, which, eroding the metalimnion, entrained the filaments of $P$. rubescens in the surface mixed layers. The formation of the surface blooms was associated with the presence of high amounts of microcystins, which in a few occasions reached concentrations between 10 and $22 \mu \mathrm{g} \mathrm{L}^{-1}$, posing potential problems for the exploitation of water resources.
\end{abstract}

Key words: Cyanobacterial blooms; cyanotoxins; Planktothrix rubescens; FluoroProbe.

Received: October 2017. Accepted: November 2017.

\section{INTRODUCTION}

Inhomogeneous vertical and horizontal distribution is a well know characteristic of phytoplankton populations (George and Edwards, 1976; George and Heaney, 1978; George, 1981; Salonen et al., 1999; Klausmeier and Litchman, 2001; Oliver and Ganf, 2002; Clegg et al., 2007; Hamilton et al., 2010). The formation of patches, thickening at selected water layers and blooms is driven by interactions between physical and biological processes (Fietz et al., 2005; Hillmer et al., 2008). Some species can change their position in the water column by actively swimming like flagellates (Clegg et al., 2007; Simmonds et al., 2015), or by regulating their buoyancy, like cyanobacteria (Walsby et al., 2004). Their distribution is conditioned by a large number of driving factors, which include the allocation of resources (Klausmeier and Litchman, 2001), the temperature gradients (Clegg et al., 2003, 2007), the light (photo response) (Rhiel et al., 1988), and the chemical gradients (Clegg et al., 2004). Vertical migrations finalized at finding optimal conditions for photosynthesis are often observed in Dinoflagellates, such as Ceratium hirudinella (O.F. Müller) Dujardin (Alexander and Imberger, 2009; Whittington et al., 2000; Whitton and Potts, 2000) and Peridinium cinctum (O.F. Müller) Ehren- berg (Regel et al., 2004). Cyanobacteria are able to regulate buoyancy through the biosynthesis of specialized gas vesicles, which enable populations to actively move to water depths with optimal growth conditions. Vertical movement rates in cyanobacteria range from a few centimetres per hour to a few meters per hour (Salmaso et al., 2014b). As expected, the highest speeds (between 0.5 and $2 \mathrm{~m} \mathrm{~h}^{-1}$ ) are reached by the large colonies of Microcystis and the filamentous aggregates of Dolichospermum and Aphanizomenon. Other data quoted in Paerl (1988) report speeds of up to $10 \mathrm{~m} \mathrm{~h}^{-1}$, whereas Oliver et al. (2012) indicated maximum velocities achieved by large aggregates of Dolichospermum circinalis (Rabenhorst ex Bornet \& Flahault) P. Wacklin, L. Hoffmann \& J. Komárek of more than $200 \mathrm{~m} \mathrm{~h}^{-1}$. The speeds achieved by individual thin filaments of cyanobacteria are much lower and limited; in the case of Planktothrix rubescens (DeCandolle ex Gomont) Anagnostidis \& Komárek, to a few centimetres per hour, typically $3-5 \mathrm{~cm} \mathrm{~h}^{-1}$, though higher speeds can be reached by the aggregation of filaments in larger units (Walsby et al., 2006).

$P$. rubescens is a typical cyanobacterium that is commonly found in deep oligo-mesotrophic waterbodies. The formation of layers of variable thickness in the metalimnetic zone is a peculiar characteristic of this species. This 
behaviour is regulated by the vertical light field and the tight coupling between carbohydrate accumulation and gas vesicle buoyancy (Walsby et al., 2004). P. rubescens gas vesicles of different strains are characterised by different strength to hydrostatic pressure in function of lake morphometry and depth (D'Alelio et al., 2011). This species is adapted to grow at low light irradiance (up to $\sim 1 \mu \mathrm{mol} \mathrm{m} \mathrm{m}^{-2} \mathrm{~s}^{-1}$ ) and this characteristic is advantageous not only in summer (filaments located in the metalimnetic layers), but also for populations developing in autumn or dragged down at greater depths during winter mixing (Walsby and Schanz, 2002). The tolerance to low light conditions is due to the presence of phycobiliproteins like phycocyanin and phycoerythrin, which are antenna pigments able to capture the whole spectrum $(400-700 \mathrm{~nm})$ of the Photosynthetic Active Radiation (PAR), providing a strong competitive advantage over other algae (Bright and Walsby, 2000; Oberhaus et al., 2007). Furthermore, when inorganic phosphorus is depleted, $P$. rubescens is able to use dissolved organic phosphorus by excretion of alkaline phosphatase (Feuillade et al., 1990).

Similarly to other toxic cyanobacteria, P. rubescens produces several microcystin (MC) congeners, most of them highly toxic for animals and humans (Meriluoto et al., 2017; Metcalf and Codd, 2012). The formation of cyanobacterial blooms in waters used for drinking purposes has been associated to the occurrence of human cancer in a number of countries (Fleming et al., 2002; Svircev et al., 2009; Ueno et al., 1996; Zhou et al., 2002). Therefore, the occurrence of toxic algal blooms in reservoirs used for drinking water production and bathing activities is of critical importance for human health (Bogialli et al., 2013; Hitzfeld et al., 2000; Hoeger et al., 2005). When lake water is derived from metalimnetic layers, particular attention must be devoted to the potential risk of contamination (Leboulanger et al., 2002; Cuypers et al., 2011). MC produce adverse effects also on zooplankton and fish (Shams et al., 2014; Sotton et al., 2014; Sukenik et al., 2015).

The methods used for the determination of phytoplankton based on the collection of discrete samples in the euphotic zone lack the necessary resolution to obtain accurate knowledge of the species distribution (Beutler et al., 2002). Determination of the fine vertical distribution of an organism with standard discrete sampling methods is difficult if not unfeasible, in particular when populations are concentrated in thin metalimnetic layers. Conversely, submersible devices measuring in continuous mode and real-time can accurately identify even the tiniest changes of biomass along the water column (Gregor et al., 2005; Humbert and Törökné, 2017). A widely used approach is based on the detection of the fluorometric signal produced by the phytoplankton photosynthetic pigments (Salmaso et al., 2017). Based on this approach, the use of the fluorometric probe has allowed the description of the spatial heterogeneity of phytoplankton along the water column (Alexander and Imberger, 2009; Longhi and Beisner, 2009; Moreno-Ostos et al., 2006; Selmeczy et al., 2016; Serra et al., 2007) and along horizontal gradients (Carraro et al., 2012; Moreno-Ostos et al., 2009; Salcher et al., 2011). The use of these probes is particularly useful to catch short-term variations in the vertical distribution of metalimnetic species like $P$. rubescens due to displacement caused by seiches. These transient changes are poorly described because of their rapid and occasional nature that are difficult to detect with the traditional sampling methodologies (Garneau et al., 2013).

Compared to the large and deep lakes, knowledge of accurate distribution of $P$. rubescens in reservoirs is less known. In this typology of waterbodies, the relationships between the vertical distribution of $P$. rubescens, the thermal structure and the light regime have been poorly investigated. With the aim to fill this gap, we performed an investigation on Lake Ledro, which is a meso-oligotrophic reservoir that has attracted the interest of scientists for paleolimnological and hydrodynamic investigations (Joannin et al., 2013; Magny et al., 2009; Milan et al., 2016; Santo et al., 2017; Simonneau et al., 2013; Vanniere et al., 2013) and that is characterized by periodic $P$. rubescens blooms (Salmaso et al., 2013). The main objective of this study is to describe the vertical distribution of $P$. rubescens based on high resolution profiling and to interpret the distribution patterns as a function of the main environmental drivers. A second objective is to evaluate the toxigenic potential of the species, in relation to the seasonality of its biomass and toxin production, as well as the main use of the lake.

\section{METHODS}

\section{Study site}

Lake Ledro is located south of the Italian Alps, $6 \mathrm{~km}$ north of Lake Garda, at $650 \mathrm{~m}$ asl. The catchment area covers ca. $131 \mathrm{~km}^{2}$. The lake is feed by two tributaries, the Massangla and the Pur rivers that are often dry. The largest amount of water originates from sub-lacustrine inlets. The outlet is the Ponale River, draining into Lake Garda at $65 \mathrm{~m}$ asl. Since 1928 the level of Lake Ledro is regulated for hydroelectric exploitation, with seasonal water level fluctuations of several meters. The lake is connected by a penstock to a pumped-storage plant on the shores of Lake Garda, from which water may be again pumped to Lake Ledro. The lake is extended in the NWSE axis, and delimited by steep slopes surrounding a relatively wide and flat central basin. Prevailing winds, in particular in the summer season, blow from SE in the morning and from NW in the afternoon (Fig. 1).

Between the beginning of the 1970's and the end of the 
1990's, Lake Ledro underwent a phase of eutrophication due to wastewater discharges, massive use of phosphate detergents and livestock. Water quality programs aimed at improving waste water treatment plants and reduction of nutrient loading into the lake begun in the 1980s.

\section{Sampling, laboratory analyses and field measurements}

Sampling and field measurements were carried out monthly in the deepest zone of the lake from June 2011 to May 2012.

At the time of sampling, profile measurements of temperature, $\mathrm{pH}$, dissolved oxygen and conductivity were made using a multiprobe CTD, Idronaut Ocean seven 316. Light (PAR) intensity was measured with a submersible irradiance sensor (LiCor 192SA). The euphotic depth $\left(\mathrm{z}_{\mathrm{eu}}\right)$ was defined as the depth at which the PAR irradiance drops to $1 \%$ of its sub-surface value, i.e. $\mathrm{z}_{\mathrm{eu}}=$ $\ln (100) \mathrm{k}_{\mathrm{d}}^{-1}$, where $\mathrm{k}_{\mathrm{d}}$ is the vertical light attenuation coefficient $\left(\mathrm{m}^{-1}\right)$ (Kirk, 2011).

Phytoplankton biomass, expressed in $\mu \mathrm{g} \mathrm{\textrm {L } ^ { - 1 }}$ of chlorophyll- $a$ (Chl- $a$ ), was measured at each sampling date by the submersible fluorometric probe FluoroProbe II (bbeMoldaenke, Kiel, Germany) (Kring et al., 2014). The device is based on the measurement of chlorophyll fluorescence emission after being excited at five different wavelengths $(450,525,570,590$, and $610 \mathrm{~nm})$ employing pulsed light-emitting diodes for the excitation of pigments present in the phytoplankton. The FluoroProbe II device allows the discrimination of four algal groups including 'green' algae (Chlorophyta and Euglenophyta), 'blue' algae containing phycocyanin (Cyanophyta), 'brown' algae (Bacillariophyta, Chrysophyta and Dinophyta), and 'red' algae containing phycoerythrin (Cryptophyta, Planktothrix). To discriminate Cryptophyta and P. rubescens signals, an additional fingerprint must be specifically assigned to the red, phycoerythrin containing $P$. rubescens (Leboulanger et al., 2002). To do this, a strain of $P$. rubescens, isolated from Lake Ledro was used to calibrate the probe, which was first immersed in GF/F pre-filtered lake water to obtain a natural lake blank, and then in lake water dominated by $P$. rubescens with known Chl- $a$ concentration. After calibration, we noted a very good correlation of the measured fluorescence with Chl- $a$ (Beutler et al., 2002). Moreover, the fluorometer records were checked against cell counting of discrete field samples. In particular, the differences between the slopes obtained by the regressions between the biovolumes of Planktothrix and the abundances obtained by the FluoroProbe at different depths were tested by computing ANCOVA statistics (Crawley, 2005).

The fine vertical and horizontal distribution of $P$. rubescens by high resolution spectrofluorometric profiles was further analyzed in one additional one-day sampling campaign carried out on 26 September 2011. The horizontal distribution was determined by 5 vertical spectrofluorometric profiles along a longitudinal transect in the main axis of the lake. Due to the small size of the lake, the time required to complete a whole horizontal survey was very short, and the collected data could be considered representative of the horizontal gradient.

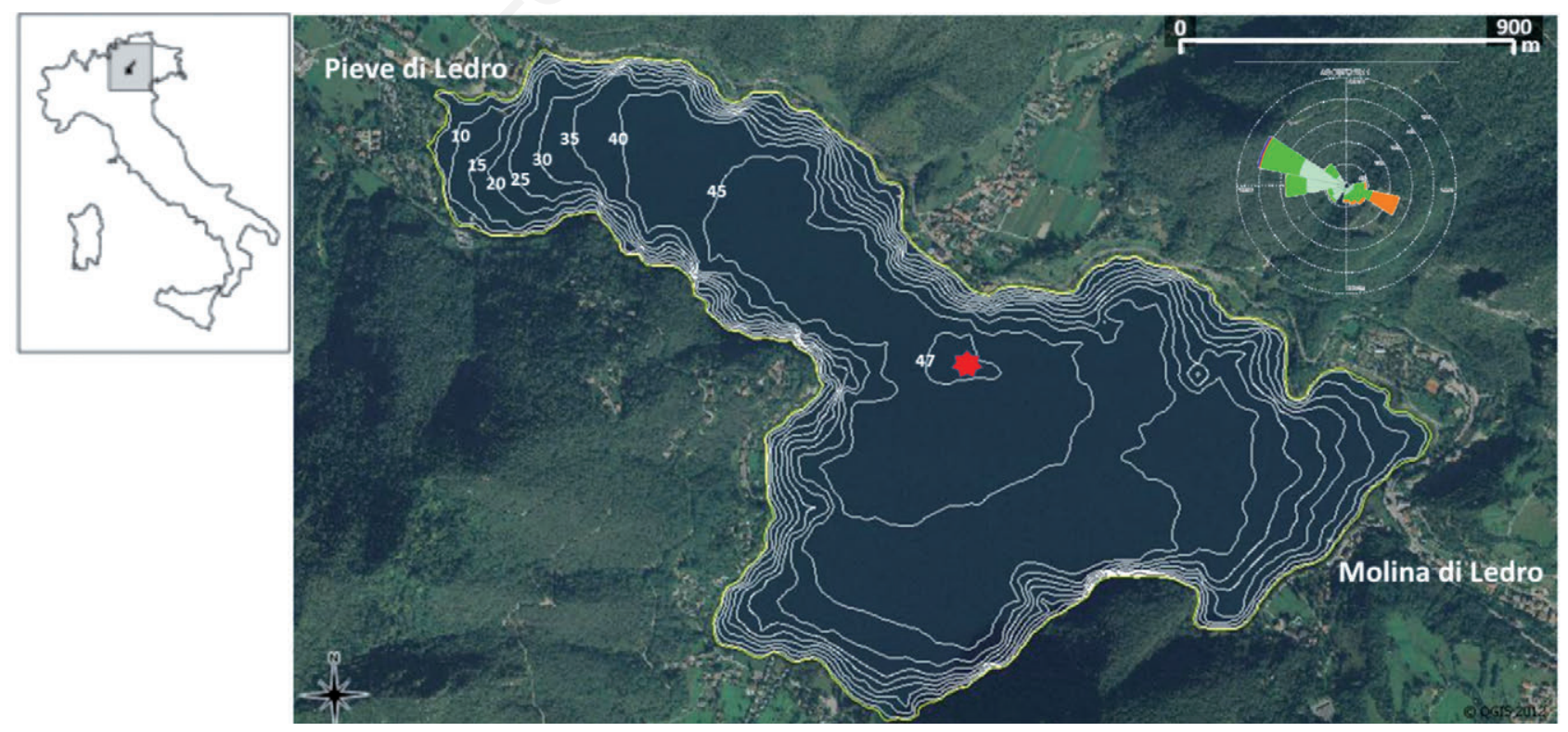

Fig. 1. Location of Lake Ledro and bathymetric map indicating the position of the sampling station (red star). The wind rose shows the wind direction and velocity $\left(\mathrm{m} \mathrm{s}^{-1}\right)$ in August 2012. 
Water samples for the chemical analyses were collected using a 5 litres Niskin bottle at $0,5,10,15,20,25$, $30,35,40 \mathrm{~m}$ and at $1 \mathrm{~m}$ from the bottom. In laboratory, total phosphorus (TP) and nitrate nitrogen $\left(\mathrm{NO}_{3}-\mathrm{N}\right)$ were measured following standard methods (APHA, 2010).

Phytoplankton samples were collected at 1, 5, 10, 15 and $20 \mathrm{~m}$; after fixation in Lugol's solution, subsamples of $10 \mathrm{~mL}$ were analyzed using inverted microscope. Biovolumes were calculated from abundances and specific biovolumes approximated to simple geometric shapes (Rott et al., 2007). In November 2011, during the onset of the bloom, two additional samples were collected.

Samples for the determination of algal toxins were collected at the surface, 10 and $20 \mathrm{~m}$ depth between June 2010 and October 2012; a few other occasional samples were collected at 5 and $15 \mathrm{~m}$. The concentration of MC and anatoxin-a (ATX) were determined by UHPLCMS/MS (Waters Acquity LC coupled to AB Sciex 4000 QTRAP mass spectrometer). Toxin extraction from algal biomass was performed after filtration of the water samples on GF/C filters. The analytical procedures were described in detail in Cerasino et al., (2016) and Cerasino and Salmaso (2012).

\section{RESULTS}

\section{Water temperature and nutrients}

Since March/April, water temperature slowly increased from $5^{\circ} \mathrm{C}$ rising to the maxima of $23.5^{\circ} \mathrm{C}$ in $\mathrm{Au}-$ gust. The lake showed a stable thermal stratification from April to November, with a stable metalimnion developing between 8 and 20-25 m. Full mixing occurred in winter, with water temperatures reaching $5^{\circ} \mathrm{C}$ in early January 2011 (Fig. 2A).

During the summer months, epilimnetic and metalimnetic TP concentrations were around 2-11 $\mu \mathrm{g} \mathrm{L}^{-1}$ and 9$35 \mu \mathrm{g} \mathrm{L}^{-1}$, respectively (Fig. 2B), whereas corresponding concentrations of $\mathrm{NO}_{3}-\mathrm{N}$ were around $0.65-0.72 \mathrm{mg} \mathrm{L}^{-1}$ and $0.52-0.72 \mathrm{mg} \mathrm{L}^{-1}$, respectively. During the winter full mixing, $\mathrm{TP}$ and $\mathrm{NO}_{3}-\mathrm{N}$ average concentrations were 15 $\mu \mathrm{g} \mathrm{L}^{-1}$ and $0.74 \mathrm{mg} \mathrm{L}^{-1}$, respectively. Overall, the annual (2012) average values ( $\pm \mathrm{SD})$ of TP and $\mathrm{NO}_{3}-\mathrm{N}$ in the epilimnetic layer $(0-20 \mathrm{~m})$ were $14 \pm 6.4 \mu \mathrm{g} \mathrm{L}^{-1}$ and $0.83 \pm 0.16$ $\mathrm{mg} \mathrm{L}^{-1}$, respectively.

\section{Transparency and Chl- $a$}

Water transparency showed lower values between November and April (2.3-5.8 m). The highest transparencies of the lake were detected between May and October (5.6$11.3 \mathrm{~m})$. The annual (2012) average value ( $\pm \mathrm{SD})$ of transparency was $6.7 \pm 2.3 \mathrm{~m}$.

Excluding a peak detected on October $2012(18.7 \mu \mathrm{g}$ $\mathrm{L}^{-1}$ ), between 0 and $10 \mathrm{~m}$, Chl- $a$ concentrations were be- tween 1 and $11 \mu \mathrm{g} \mathrm{L}^{-1}$. In the layer 15-20 m, concentrations were much higher, ranging between 1.5 and $34 \mu \mathrm{g}$ $\mathrm{L}^{-1}$. The annual (2012) average value ( $\left.\pm \mathrm{SD}\right)$ of Chl- $a$ was $6.6 \pm 6.6 \mu \mathrm{g} \mathrm{L} \mathrm{L}^{-1}$.

\section{Phytoplankton groups}

Cyanobacteria were the main phytoplankton group developing in Lake Ledro (Fig. 3). Excluding the first sampling date, their contribution varied between $30 \%$ and $93 \%$ of the total determined fraction. The main species within this group was represented by $P$. rubescens, whose fraction represented between $98 \%$ and $100 \%$ on the total cyanobacteria biovolume. The other abundant groups were represented by Bacillariophyta (1-65\%; mostly Fragilaria crotonensis Kitton, Asterionella formosa Hassal, Cyclotella spp., Diatoma elongata (Lyngbye) C. Agardh and Fragilaria spp.) and Chrysophyta ( $<1-40 \%$; mostly Dinobryon spp. and Mallomonas spp.).

The biovolumes of $P$. rubescens estimated by the microscopic countings were closely correlated with the abundances estimated by the FluoroProbe. Excluding two outliers detected in June $(15 \mathrm{~m})$ and October $2012(10 \mathrm{~m})$, the relationships between these two estimates were always highly significant (Tab. 1). The slope of the relationship between the two variables was slightly higher at the surface $(0-2 \mathrm{~m})$ compared to the deeper layers, particularly at $20 \mathrm{~m}$ (ANCOVA, $\mathrm{P}<0.01$ ), indicating a greater fluorometric response of $P$. rubescens in the layer around the metalimnion.

\section{Time and depth distribution of $P$. rubescens}

In the whole study period, the temporal development of P. rubescens as estimated by the FluoroProbe showed a clear seasonal pattern (Fig. 2C), which was confirmed, in the first $20 \mathrm{~m}$, by the biovolume estimates obtained by microscopic countings (Fig. 2D). During the maximum thermal stratification (June-October) P. rubescens was always located in the metalimnetic layer, at the highest density gradient, with maximum biovolumes ranging between 7000 $\mathrm{mm}^{3} \mathrm{~m}^{-3}$ in 2011 and $10700 \mathrm{~mm}^{3} \mathrm{~m}^{-3}$ in 2012. High oxygen saturation was measured immediately above the peak of $P$. rubescens with values up to $190 \%$ (Figure not shown).

In October, with the decreasing of air temperature, epilimnetic water body cooled and progressively mixed down to the depth of the P. rubescens layer, causing the entrainment of filaments in the mixolimnion. Eventually, with the lake fully mixed, the filaments were homogeneously distributed down to the lake bottom (Fig. 2C). In spring, at the onset of thermal stratification, a small subsurface maximum in the P. rubescens populations began to develop. During the maximum thermal stratification (June-October), the euphotic depth ranged between 10 and $19 \mathrm{~m}$ and the maximum P. rubescens density ( peak $_{\max }$ ) 

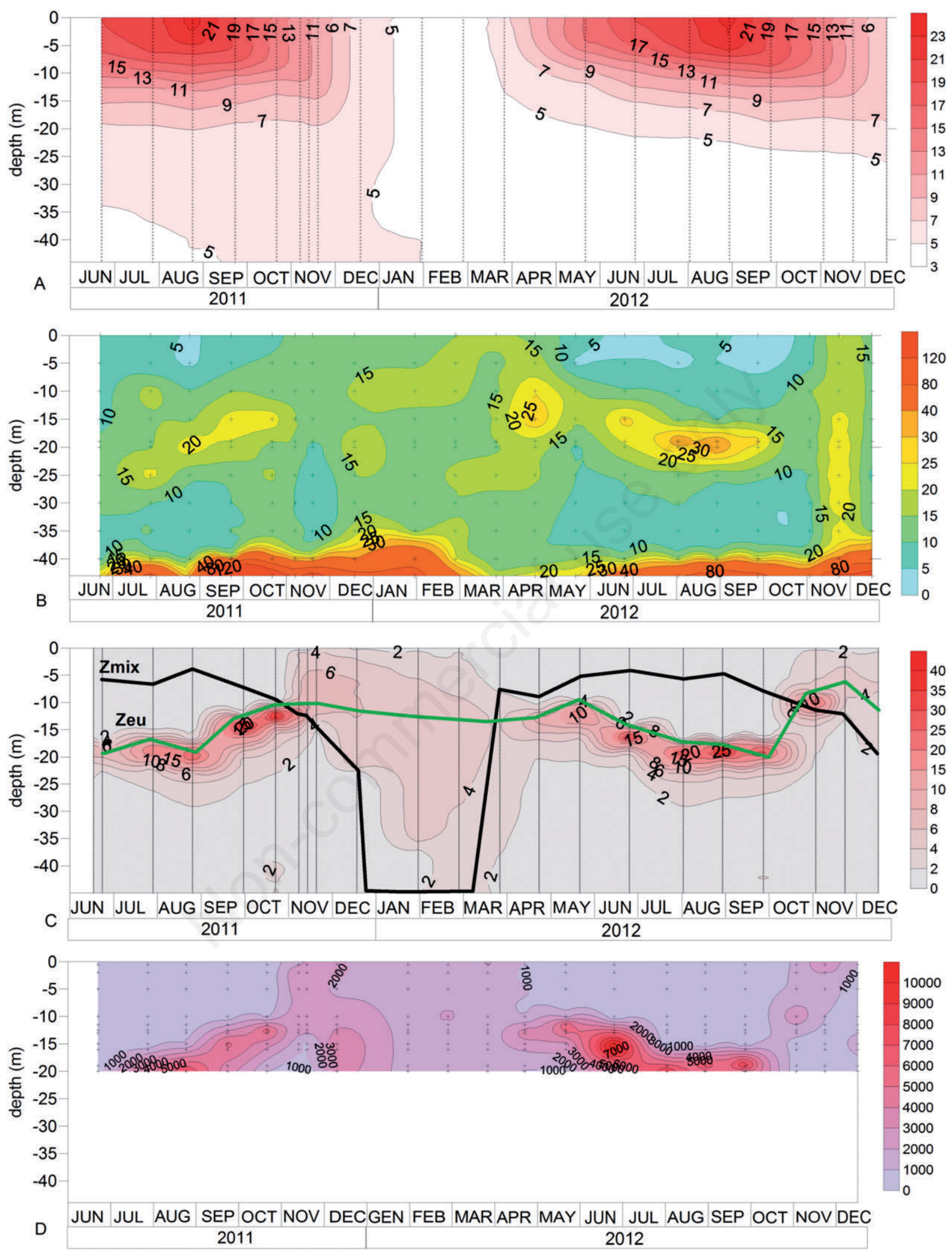

Fig. 2. Temporal development of $(\mathrm{A})$ water temperature $\left({ }^{\circ} \mathrm{C}\right)$; (B) total phosphorus $\left(\mu \mathrm{g} \mathrm{L}^{-1}\right)$; $(\mathrm{C})$ biomass of $P$. rubescens as determined by the FluoroProbe (Chl- $a$ eq, $\mu \mathrm{g} \mathrm{L}^{-1}$ ); and (D) biomass of $P$. rubescens estimated by microscopic countings $\left(\mathrm{mm}^{3} \mathrm{~m}^{-3}\right)$ between the surface and $20 \mathrm{~m}$ in Lake Ledro. In (C) the black and green continuous lines indicate the mixing layer and the euphotic depths, respectively. Data refer to the period between June 2011 and December 2012. 
varied between 12 and $19 \mathrm{~m}$ (Fig. 2C). The maximum development of $P$. rubescens was located at about $1.5 \mathrm{~m}$ below the depth of the euphotic zone. Moreover, $1 \%$ of the subsurface light intensity $\left(\mathrm{z}_{\mathrm{eu}}\right)$ ranged between 6 and $20 \mu \mathrm{mol} \mathrm{m} \mathrm{m}^{-2} \mathrm{~s}^{-1}$; and light intensities at the depth of the maximum peak of Planktothrix ranged between 2 and 11 $\mu \mathrm{mol} \mathrm{m} \mathrm{s}^{-2}$ (average $6 \pm 2.7 \mu \mathrm{mol} \mathrm{m} \mathrm{m}^{-2} \mathrm{~s}^{-1}$ ). Overall, in the stratification period (April-November), the depths corresponding to the maximum densities of $P$. rubescens were strongly and positively correlated with the variations in the euphotic depth values $\left(r^{2}=0.94 ; \mathrm{P}<0.001\right)$ (Fig. 4).

The abundances of Planktothrix obtained by the FluoroProbe (expressed as $\mu \mathrm{g} \mathrm{Chl-} a$ eq L L ${ }^{-1}$ ) were integrated from the water surface to 40-meter depth to calculate the mean total biomass of $P$. rubescens per surface unit $\left(\mathrm{m}^{2}\right)$ (Fig. 5). Values increased from $0.03 \mathrm{~g} \mathrm{Chl-} a \mathrm{eq} \mathrm{m}^{-2}$ in June 2011 to over $0.13 \mathrm{~g}$ Chl- $a$ eq m$^{-2}$ in September 2011; values fluctuated between 0.05 and $0.13 \mathrm{~g} \mathrm{Chl}-a \mathrm{eq} \mathrm{m}^{-2}$ in the following months.

The one-day survey carried out on September 2011 along the main axis of the lake allowed the identification of consistent variations in the vertical distributions of the $P$. rubescens biomass persisting along the major axis of the lake. The depths of the $P$. rubescens peaks were a little bit shallower in the NW zone of the lake compared to the SE zone, with a difference of up to $4 \mathrm{~m}$ between the two extremities (Fig. 6). Heterogeneity was documented not only in the vertical distribution of $P$. rubescens, but also in the horizontal, with lower biomasses at the NW end of the lake and higher biomasses at the SE end (Fig. 6).

During the investigation, $P$. rubescens occasionally formed extended surface blooms, which were particularly apparent along the shores, as in the episode occurred between the end of October and the beginning of November 2011 (Fig. 7A). This bloom was strictly localized at the surface and thicket along the shores and bays, and therefore no relevant signals were recorded by the FluoroProbe (Fig. 2C). In other occasions, however, occurred before and after the activities carried out in this research, surface blooms were particularly apparent and extended, as in the events of autumn 2009, spring 2010, and December 2013 (Fig. 7B, and Wilmotte et al., 2017: Fig. 4.1 C,D).

Total MC concentrations varied between $1 \mathrm{ng} \mathrm{L}^{-1}$ and $4.4 \mu \mathrm{g} \mathrm{L}^{-1}$ (August 2011, $20 \mathrm{~m}$ ). Generally, the highest concentrations $\left(>0.2 \mu \mathrm{g} \mathrm{L}^{-1}\right)$ were detected at $20 \mathrm{~m}$, i.e. the maximum depth at which sampling for cyanotoxins analysis was performed; during maximum stratification, between July and September, MC concentrations at $20 \mathrm{~m}$ were always higher than $1 \mu \mathrm{g} \mathrm{L}^{-1}$. Overall, the mean concentrations at $20 \mathrm{~m}$ were significantly higher $\left(1.3 \mu \mathrm{g} \mathrm{L}^{-1}\right)$ than those measured at the surface $\left(0.35 \mu \mathrm{g} \mathrm{L}^{-1}\right)$ and $10 \mathrm{~m}$ depth $\left(0.52 \mu \mathrm{g} \mathrm{L}^{-1}\right)$ (ANOVA and Tukey's test, $\left.\mathrm{P}<0.001\right)$ (Fig. 8). The more abundant $\mathrm{MC}$ congeners were represented by MC-RRdm and MC-LRdm. Other minor MC congeners

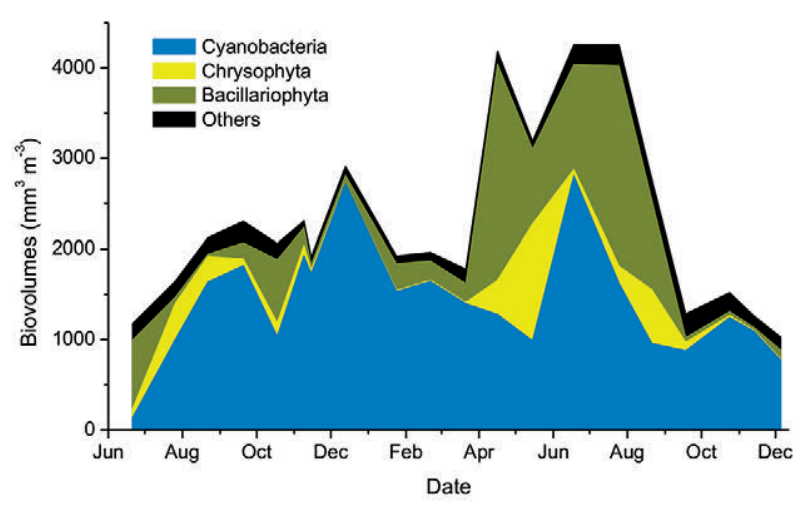

Fig. 3. Temporal development of the dominant phytoplankton phyla between June 2011 and December 2012.

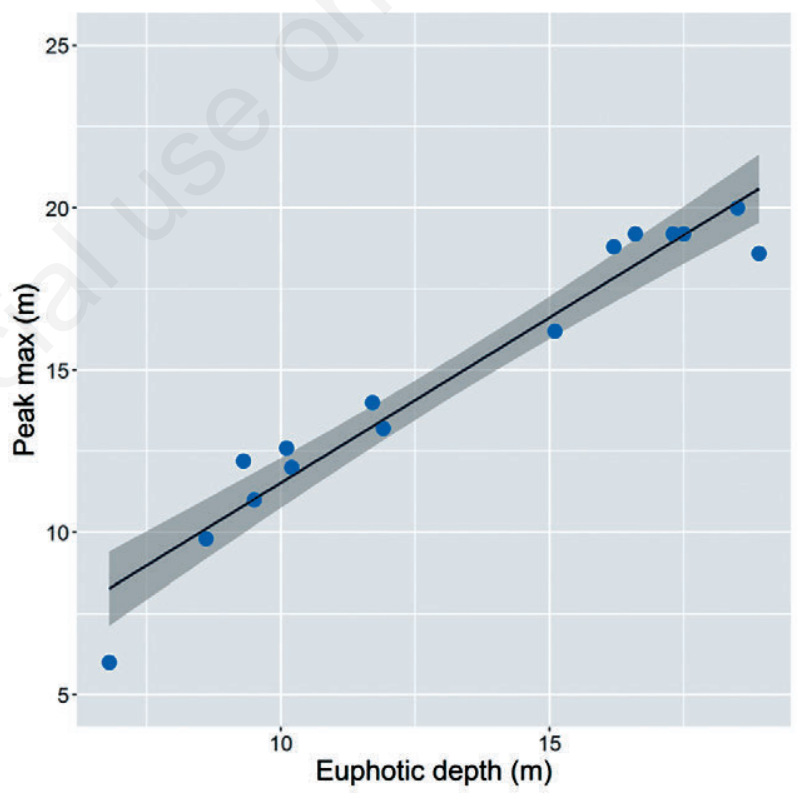

Fig. 4. Relationship between the depth of P. rubescens maximum densities $\left(\right.$ peak $\left._{\max }\right)$ and the euphotic depth $\left(\mathrm{z}_{\mathrm{eu}}\right)$; peak $\mathrm{p}_{\max }=$ $1.35+1.02 \times \mathrm{Z}_{\text {eu }}, r^{2}=0.94, \mathrm{P}<0.001$. The shaded area indicates the $95 \%$ confidence levels.

Tab. 1. Regression between the biovolume values of $P$. rubescens estimated by microscopic countings $\left(\mathrm{mm}^{3}\right.$ $\mathrm{L}^{-1}$ ) and abundances estimated by the FluoroProbe (equivalents of Chl- $a \mu \mathrm{g} \mathrm{L}^{-1}$ ). The parameters a (intercept) and b (slope) were obtained from the regression $\mathrm{y}=\mathrm{a}+\mathrm{b} \times \mathrm{x}$, where $\mathrm{y}$ is the biovolumes and $\mathrm{x}$ the abundances estimated by the FluoroProbe.

\begin{tabular}{lcccc} 
& $\mathbf{a}$ & $\mathbf{b}$ & $\mathbf{r} 2$ & $\mathbf{P}$ \\
$0-2 \mathrm{~m}$ & 0.14 & 0.56 & 0.79 & $<0.001$ \\
$5 \mathrm{~m}$ & 0.15 & 0.34 & 0.79 & $<0.001$ \\
\hline $10 \mathrm{~m}$ & -0.02 & 0.36 & 0.88 & $<0.001$ \\
$15 \mathrm{~m}$ & -0.15 & 0.42 & 0.83 & $<0.001$ \\
\hline $20 \mathrm{~m}$ & 0.37 & 0.27 & 0.86 & $<0.001$ \\
\hline
\end{tabular}


were MC-HtyrRdm, and MC-RR and MC-LR. Conversely, the neurotoxic alkaloid ATX was always detected with very low concentrations $\left(<0.05 \mu \mathrm{g} \mathrm{L}^{-1}\right)$. Overall, the total MC concentrations showed a strong relationship with the biovolumes of $P$. rubescens (Fig. 9).

During the blooms, the concentrations of $\mathrm{MC}$ at the surface reached quite high values. In a few samples collected at the surface during one of these events (3 November 2011), the total concentrations of MC were between 8.4 and $10.0 \mu \mathrm{g} \mathrm{L}^{-1}$. An occasional and isolated high value was recorded also at the very surface in March 2012 $\left(9 \mu \mathrm{g} \mathrm{L}^{-1}\right)$. Before this investigation, total MC concentration measured on a surface sample collected during a bloom on 3 March 2010 was $21.8 \mu \mathrm{g} \mathrm{L} \mathrm{L}^{-1}$. In both cases, the dominant congeners were MC-RRdm and MC-LRdm.

\section{DISCUSSION}

\section{Ecological and trophic characterization}

Populations of $P$. rubescens have been widely studied all over Europe. Traditionally, the first and more numer-

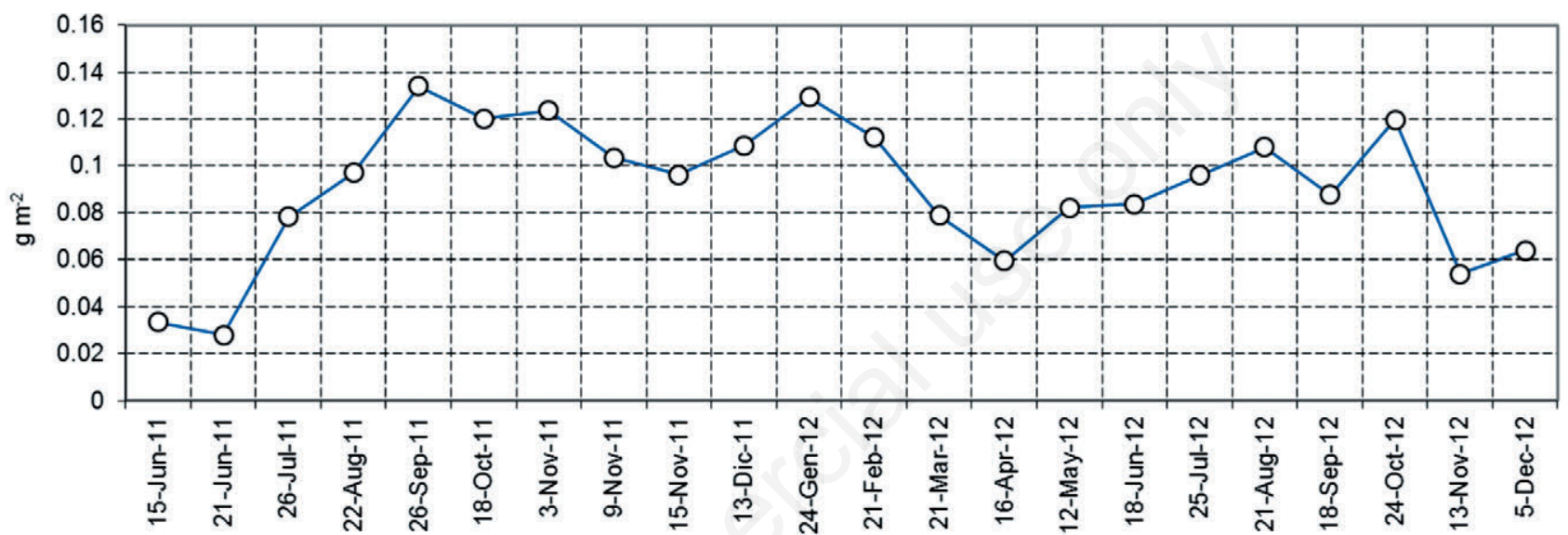

Fig. 5. Integrals of the P. rubescens biovolume (g Chl- $a$ eq $\mathrm{m}^{-2}$ ) in Lake Ledro computed from the surface to $40 \mathrm{~m}$ depth.

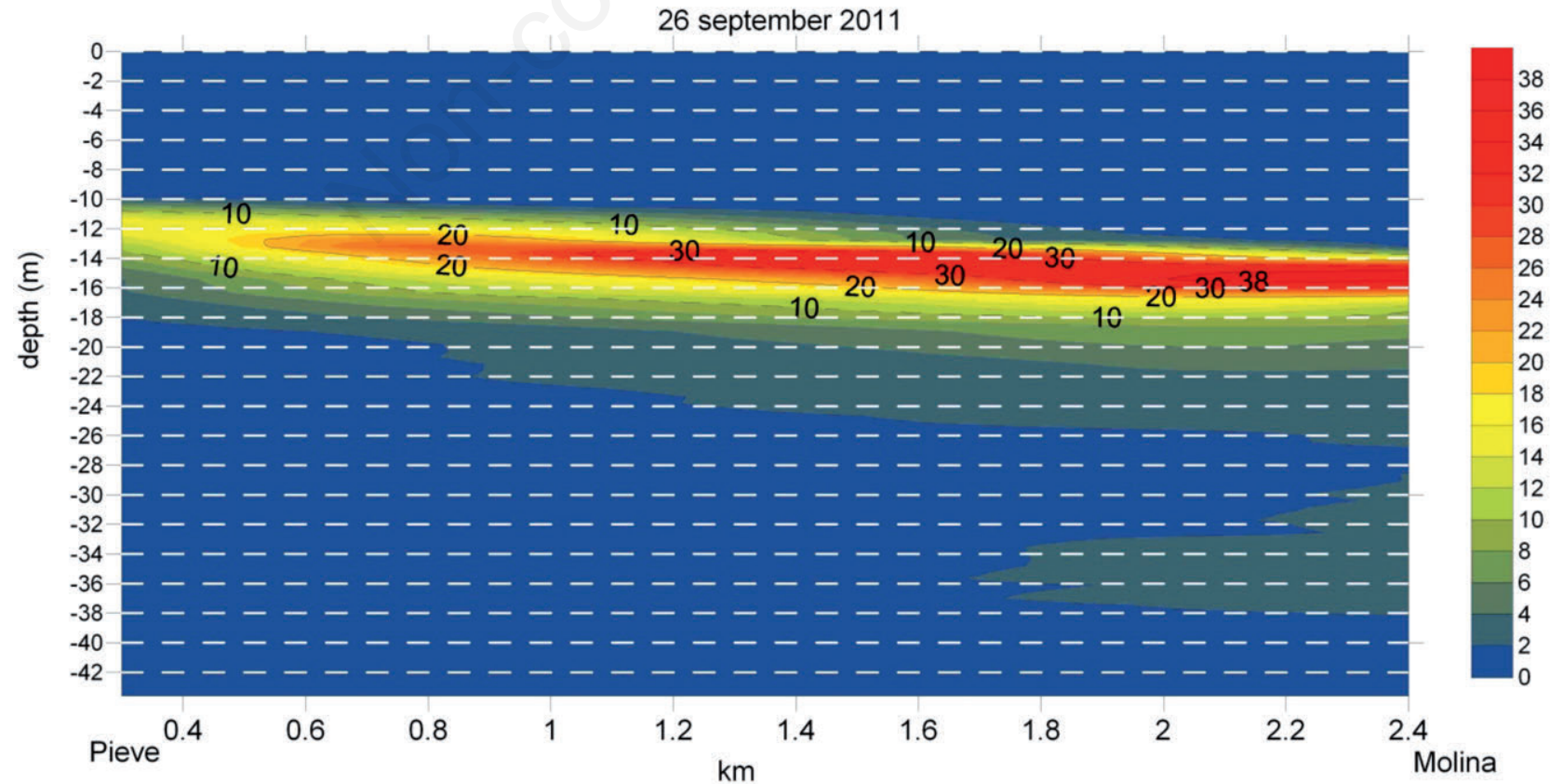

Fig. 6. Two dimensional transects of the distribution of P. rubescens biomass obtained by the FluoroProbe as Chl- $a$ eq $\left(\mu \mathrm{g} \mathrm{L} \mathrm{L}^{-1}\right)$ along the main axis of the lake carried out on 26 September 2011. 
ous studies were carried out in the subalpine and perialpine regions (Jacquet et al., 2005; Legnani et al., 2005; Kurmayer and Gumpenberger, 2006; Salmaso et al., 2006; Walsby et al., 2006), Central (Salmaso and Padisák, 2007) and Northern Europe (Halstvedt et al., 2007). For this reason, traditionally this species has been considered a coldwater stenotherm cyanobacterium. Nevertheless, besides the more recent discovery of populations living in Eastern Europe (Vasas et al., 2013), records of this species were documented in many Mediterranean regions, including Central and Southern Italy ( Messineo et al., 2006; Assennato et al., 2010), Sicily (Naselli-Flores and Barone, 2000), Spain (Almodóvar et al., 2004), Greece (Vareli et al., 2009) and Turkey (Akçaalan et al., 2014; Köker et al., 2017). More recently, this species has also been identified in Northern Africa (Guellati et al., 2017). The taxonomic position of this species has been widely investigated based both on phenotypic characters (Komárek and Anagnostidis, 2005) and genetic markers (D'Alelio et al., 2013; Gaget et al., 2015; Kurmayer et al., 2015; Salmaso et al., 2016; Suda et al., 2002). Similarly, owing the impact on water quality of the lakes affected by its development, the ecology and trophic preferences of $P$. rubescens have been widely studied in several lakes (Becker et al., 2005; Walsby, 2005; Reynolds, 2006).

Unlike many other cyanobacterial species, P. rubescens is usually found in lakes characterized by (oligo-) mesotrophic conditions (Reynolds et al., 2002). In this regard, Lake Ledro confirms the oligo-mesotrophic character of this species; based on the epilimnetic (0-20) annual (2012) values of TP, Chl- $a$ and transparency, it can be classified as meso-oligotrophic. P. rubescens has the tendency to disappear or develop with rare filaments in oligotrophic and high eutrophic lakes (Jacquet et al., 2014). It has been described as a species that develops during the recovery and oligotrophication processes (Ernst et al., 2001). For example, in Lake Pusiano this species was identified in the early 2000s after the implementation of measures that reduced the wastewater and nutrient loads into the waterbody (Vuillermoz et al., 2006). Similarly, P. rubescens gave rise to blooming episodes in Lake Zürich during the early stages of eutrophication, then it disappeared during the eutrophic period, and finally reappeared after reduction of nutrient loads following improvement of sewage treatment plants (Lampert and Sommer, 2007). While the low development of $P$. rubescens in oligotrophic environments is due to deficient concentrations of nutrients or organic matter (Zotina et al., 2003) not sufficient to sustain high growth rates, its decrease in eutrophic environments is due to an excessive reduction of light intensity along the water column and complete metalimnetic darkening due to epilimnetic shading by other algal groups outcompeting cyanobacteria (e.g., see case studies in Jeppesen et al., 2005). Conversely, during summer, in medium enriched lakes, $P$. rubescens is strictly localized in the illuminated metalimnetic layers. The metalimnion is characterized by a strong density gradient with a strong buoyancy force that prevents mixing avoiding entrainment in surface strata (Walsby et al., 2004; next section). With an intensity of light saturation $I_{\mathrm{k}}$ (which indicates the transition from a light-limited to a light-saturated condition) of around 10 $\mu \mathrm{mol} \mathrm{m} \mathrm{m}^{2} \mathrm{~s}^{-1}$ and light inhibition at around $130 \mu \mathrm{mol} \mathrm{m} \mathrm{m}^{2}$ $\mathrm{s}^{-1}$, P. rubescens can be considered a true shade phytoplankter, able to grow in low light conditions (Lampert and

A
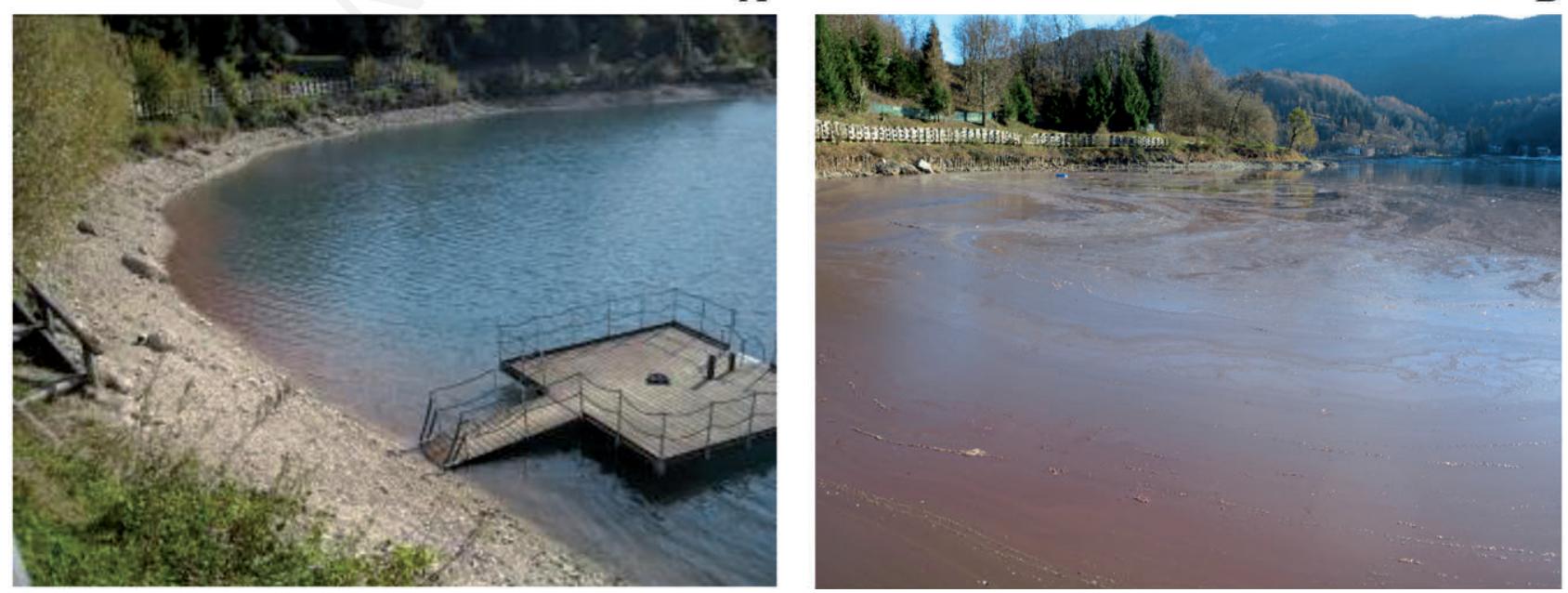

Fig. 7. Surface blooms of P. rubescens observed on (A) 28 October 2011 and (B) December 2013 on the northern shore of Lake Ledro. 
Sommer, 2007). Photosynthesis in this species is still possible with dim illumination intensities of up to 3-4 $\mu \mathrm{mol}$ $\mathrm{m}^{-2} \mathrm{~s}^{-1}$. In Lake Ledro, the light intensities in the zone of the greater development of this cyanobacterium (between

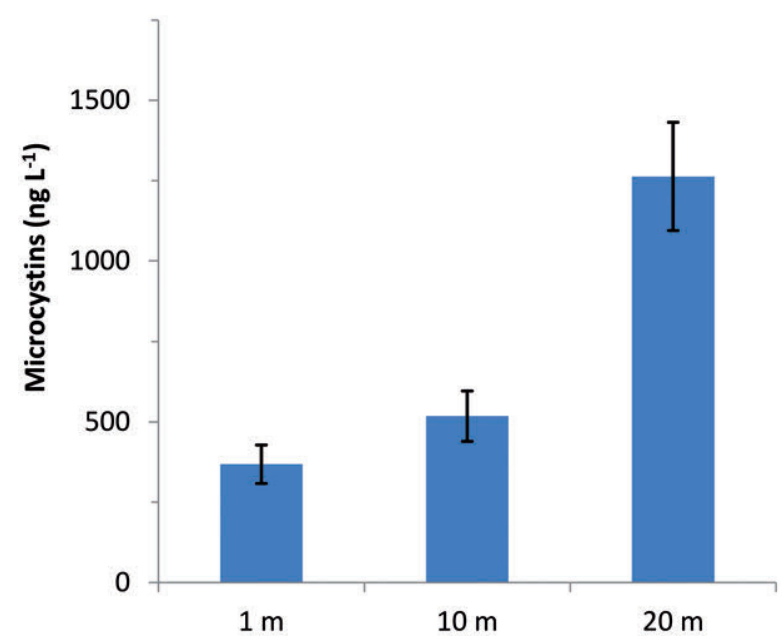

Fig. 8. Mean values of total MC measured at the surface, $10 \mathrm{~m}$ and $20 \mathrm{~m}$; data refer to samples collected between June 2011 and December 2012. The vertical bars indicate the standard errors of the means.

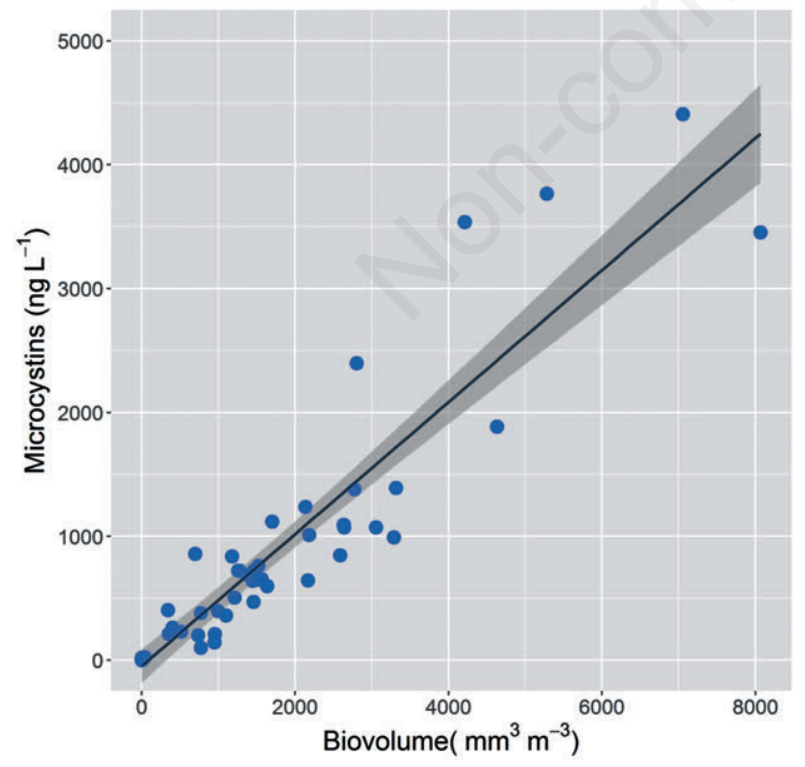

Fig. 9. Relationships between $\mathrm{MC}$ and biovolumes of $P$. rubescens $\left(\mathrm{B}_{\mathrm{Pr}}\right)$ in Lake Ledro; $\mathrm{MC}=-46.6+0.53 \times \mathrm{B}_{\mathrm{Pr}}, r^{2}=0.86$, $\mathrm{P}<0.001$. Data refer to samples collected in the period between June 2010 and October 2012 at the surface and at $10 \mathrm{~m}$ and 20 $\mathrm{m}$; a few occasional samples (8) were collected at $5 \mathrm{~m}$ and 15 $\mathrm{m}$. The shaded area indicates the $95 \%$ confidence levels. the euphotic depth and the layer of maximum development of the species) were between 2 and $20 \mu \mathrm{mol}$ $\mathrm{m}^{-2} \mathrm{~s}^{-1}$, i.e. values within the light intensities required to sustain growth. Therefore, in general, the establishment of conditions suitable for the growth of Planktothrix requires a balance between the vertical formation of the metalimnetic layer (where species can concentrate) and its illumination, which, in turn, is controlled by the algal production and shading by other competing species in the epilimnetic layers and, ultimately, trophic state. In Lake Ledro, these conditions appeared fully met.

In the metalimnion, cyanobacteria can exploit the nutrients available at the interface between the hypolimnion and the surface depleted layers (Dokulil and Teubner, 2012). In Lake Ledro, during the stratification period, SRP and TP concentrations at the surface were quite low, below $5 \mu \mathrm{g} \mathrm{L}^{-1}$. The higher concentrations of TP detected around the metalimnion were due to the phosphorus accumulated in the organic matter produced by phytoplankton (mostly by P. rubescens) and to the higher availability of nutrients at the interface between epi- and hypolimnion. Overall, this indicated both the ability of cyanobacteria located in the metalimnion to take advantage of nutrients available in the deeper layers and the general availability of a source of nutrients stored in the metalimnion potentially available through bacterial recycling and mineralization processes.

\section{Metalimnetic positioning and bloom formation}

In $P$. rubescens, the ability to control the vertical movement and positioning is mostly controlled by the biosynthesis of gas vesicles and by the fraction of carbohydrates (ballast) produced by photosynthesis within the cell (reviewed in Salmaso et al., 2014b). The genes encoding the proteins that constitute the gas vesicles in $P$. rubescens populations isolated from several southern subalpine lakes have been studied by D'Alelio et al. (2011). These authors found that the populations of $P$. rubescens living in Lake Ledro were represented by specific genotypes possessing gas vesicles less resistant to the hydrostatic pressure compared to the populations living in the larger and deeper lakes characterized by higher mixing depths, such as, among the others, lakes Garda, Como and Maggiore. Moreover, the limited maximum depth of Lake Ledro $(43 \mathrm{~m})$ could assure the survival of the population of $P$. rubescens during winter mixing, giving a competitive advantage to the filaments, which could employ the resources available at the beginning of the vegetative period. In the well illuminated surface layers, the floating caused by the gas vesicles is counterbalanced by higher carbohydrate production, and cells, becoming denser than water, sink. At higher depths and lower light intensity, the production of carbohydrates is low and the cells decrease their ballast and density, positioning themselves in the 
metalimnetic layer at a depth (defined neutral buoyancy depth, $z_{\mathrm{n}}$ ) (Walsby and Schanz, 2002; Walsby et al., 2006). In Lake Zurich, filaments of $P$. rubescens showed neutral buoyancy after being exposed to PAR illumination of $6.5 \mu \mathrm{mol} \mathrm{m}{ }^{-2} \mathrm{~s}^{-1}$ and photoperiod of 12:12 hours, corresponding to a daily insolation, $Q_{\mathrm{n}}$, of $0.28 \mathrm{~mol} \mathrm{~m}^{-2} \mathrm{~d}^{-1}$ (Walsby et al., 2004; Walsby, 2005). Interestingly, in Lake Ledro the above PAR illumination value is equivalent to the mean light intensity that has been measured in correspondence of the maximum metalimnetic development of P. rubescens in the stratified period (i.e., $6 \mu \mathrm{mol} \mathrm{m}^{-2} \mathrm{~s}^{-1}$ ). The $z_{\mathrm{n}}$ values increases or decreases in response to high or low brightness conditions, respectively. During the warmer months, when $z_{\mathrm{n}}$ exceeds the mixed depth $z_{\mathrm{m}}, P$. rubescens will be stratified in the metalimnion (Fig. 2 C,D). In autumn, with the concurrent decrease of the depth of neutral buoyancy $z_{\mathrm{n}}$, which is caused by the decrease in light intensity and day length, and the deepening of the mixed layer, $z_{\text {mix }}$, the metalimnetic thickening of $P$. rubescens begins to erode. When $z_{\text {mix }}>z_{\mathrm{n}}$, the filaments are mixed and transported up to the surface, experimenting higher daily average insolation and decreasing buoyancy (Micheletti et al., 1998; Walsby and Schanz, 2002). With further water cooling and increase in $z_{\mathrm{m}}$, the average daily insolation $Q_{\mathrm{v}}$ experienced by the filaments of $P$. rubescens decreases to values equivalent or below to $Q_{\mathrm{n}}$, making filaments able to float again and forming, during calm windy conditions, surface blooms (Walsby et al., 2006). Once at the surface, and in the presence of light breezes, the filaments can rapidly move from the pelagic zone to the lake shores and bays (Fig. 7A-B). Conversely, as summarized by Cuypers et al.,(2011) and Kurmayer et al., (2015), internal waves can induce pronounced vertical displacements: in a seasonal study these authors described vertical shifts up to $10 \mathrm{~m}$ for P. rubescens.

The increase in buoyancy and the entrainment of the filaments of $P$. rubescens during the autumn and winter months are the mechanisms explaining the spectacular blooms that have been described in many lakes. These events often influenced the historical folklores and gave rise, for example, to the legend of the Red Cock in Lake Stechlin (Padisák et al., 2010) and to the myth associated with the red discoloration of Lake Murten in Switzerland. The latter one was interpreted as the blood of Burgundian soldiers thrown in the lake in 1476, after the siege of Murten (Walsby et al., 2006). Besides Lake Ledro, in the Italian peninsula intense red autumn and winter blooms were documented in lakes Iseo, Pusiano, Occhito and Vico (Manganelli et al., 2014; Salmaso et al., 2014b).

\section{Biovolume levels and cyanotoxins}

The maximum biovolumes attained by $P$. rubescens in the metalimnetic layer during the warmest months (generally between 3000 and $8000 \mathrm{~mm}^{3} \mathrm{~m}^{-3}$ ) were one order of magnitude higher than those usually recorded in oligotrophic environments, such as the largest and oligotrophic subalpine lakes; conversely, these values were of the same order of magnitude of the biovolumes recorded in smaller waterbodies, such as lakes Occhito and Pusiano (Salmaso et al., 2014a, 2014b). Similarly to Lake Ledro, these two lakes showed the formation of huge surface water blooms. In Lake Occhito, the blooms raised serious concerns due to the use of the waters contaminated by MC for drinking purposes (Di Gregorio et al., 2017).

The concentrations of MC recorded in Lake Ledro showed a clear relationship with the biovolumes of $P$. rubescens. The slope of the regression (Fig. 9) gives an estimate of the increase of MC per unit increase of biovolume ( $\mathrm{fg} \mu \mathrm{m}^{-3}$ ), therefore providing an estimate of the cell quota, CQ, the quantity of toxins per unit biovolume. Though based on a more extended dataset of Lake Ledro, including also data collected between $5 \mathrm{~m}$ and $15 \mathrm{~m}$, the slope relating MC and the biovolumes of $P$. rubescens obtained in this work (0.53) was coincident with the slopes computed by Salmaso et al., $(2013,2014 a)$ using both ordinary least square linear regressions (0.51) and Bayesian analyses $(0.51)$. These CQ were the same as those estimated from the samples collected in Lake Garda, suggesting the presence of similar chemotype populations in the two lakes. Overall, the concentrations recorded in Lake Ledro occasionally presented values above $1 \mu \mathrm{g} \mathrm{L}^{-1}$, which is the limit set by the recent Italian regulatory level for $\mathrm{MC}$ in drinking water. However, it is worth to highlight that the highest concentrations were recorded during the summer months in the metalimnetic layers, whereas at the surface occasional values $>1 \mu \mathrm{g} \mathrm{L}^{-1}$ were found only during the winter months. The few measurements made during the surface blooms confirmed the presence of high (even $>20 \mu \mathrm{g} \mathrm{L}^{-1}$ ) concentrations of MC. Nevertheless, as highlighted in previous investigations, a more realistic assessment of toxicity and potential adverse health effects should take into account the actual toxicity of the more abundant congeners (Cerasino and Salmaso, 2012; Salmaso et al., 2014a). Assuming MC-LR as the reference $\mathrm{MC}$ with a Toxic Equivalent Factor, $\mathrm{TEF}=1$, the most abundant $\mathrm{MC}$ congeners in the populations of $P$. rubescens living in Lake Ledro, i.e. MC-RRdm and MCLRdm, have TEFs around 4 and 3 times lower than MCLR, respectively (Wolf and Frank, 2002).

\section{CONCLUSIONS}

Among cyanobacteria, $P$. rubescens is a species that is well adapted to develop in moderately nutrient rich and deep lakes, such as Lake Ledro. In this typology of waterbodies, the competitive abilities of this species rely in its capacity to stand and growth in the dimly illuminated metalimnetic layer during the warmer months. As a matter 
of fact, during summer (when the touristic presence around the lake is at the top) the lake water is characterized by 'clean' conditions and high transparency, with values generally higher than $8 \mathrm{~m}$. Paradoxically, the lowest transparency values in this lake are measured during the winter months, after the entraining of the cyanobacterium in the mixed layer. The formation of extended red water blooms in this deep meso-oligotrophic lake characterized by the formation of a deep metalimnion is a phenomenon common to other lakes with same characteristics.

$P$. rubescens populations in Lake Ledro were always toxic in the considered period. Hepatotoxic MCs were constantly associated to the cyanobacterium presence, while the presence of other toxins (namely, the neurotoxic ATX) was not significant. The total MC distribution in the water column was related to $P$. rubescens distribution showing maximum values in the metalimnetic layer (highest value: $4.4 \mu \mathrm{g} \mathrm{L}^{-1}$ recorded in August 2011). The MC profile resulted to be constant, with the two variants MC-RRdm and MC-LRdm always dominating. The cal-

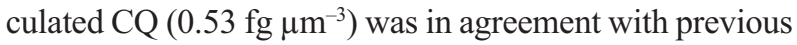
observations (Salmaso et al., 2013, 2014a). All these evidences suggest that the chemotype of $P$. rubescens is constant in Lake Ledro.

The development of very dense $P$. rubescens blooms associated to consistent production of $\mathrm{MC}$ deserve further investigation of the ecological and toxicological aspects aimed, for instance, at assessing the potential impact of such high toxin levels on the aquatic flora and fauna (fish community), and on the complete genetic and genomic characterization of toxigenic planktic species, including $P$. rubescens and also other cyanobacteria living in the lake.

\section{ACKNOWLEDGEMENTS}

This study was financed by the Autonomous Province of Trento (Projects Ledro I-II). We are grateful to our colleagues in FEM, in particular L. Ress, M. Tarter and A. Zampedri, for their support in the laboratory activities. Special thanks are due to the dive team of the fire department of the Autonomous Province of Trento for helping in the installation of the equipment in lake waters. We are grateful to two anonymous reviewers for valuable comments and suggestions on the manuscript.

\section{REFERENCES}

Akçaalan R, Köker L, Gürevin C, Albay M, 2014. Planktothrix rubescens: a perennial presence and toxicity in Lake Sapanca. Turk. J. Bot. 38:782-798.

Alexander R, Imberger J, 2009. Spatial distribution of motile phytoplankton in a stratified reservoir: the physical controls on patch formation. J. Plankton. Res. 31:101-118.

Almodóvar A, Nicola G, Nuevo M, 2004. Effects of a bloom of
Planktothrix rubescens on the fish community of a Spanish reservoir. Limnetica 23:167-178.

APHA, 2010. Standard methods for the examination of water and wastewater. 19th ed. American Public Health Association, Washington.

Assennato G, Blonda M, Cudillo B, Gifuni S, Petruzzelli MR, Pastorelli AM, Ungaro N, 2010. Cyanobacteria bloom in the Occhito artificial lake (southern Italy): relationship between Planktothrix rubescens density and microcystin concentration. Fresen. Environmental Bulletin 19:1795-1801.

Becker S, Hayes PK, Walsby AE, 2005. Different gvpC length variants are transcribed within single filaments of the cyanobacterium Planktothrix rubescens. Microbiology 151:59-67.

Beutler M, Wiltshire KH, Meyer B, Moldaenke C, Lüring C, Meyerhöfer M, Hansen UP, Dau H, 2002. A fluorometric method for the differentiation of algal populations in vivo and in situ. Photosynth. Res. 72:39-53.

Bogialli S, di Gregorio FN, Lucentini L, Ferretti E, Ottaviani M, Ungaro N, Abis PP, de Grazia MC, 2013. Management of a toxic cyanobacterium bloom (Planktothrix rubescens) affecting an Italian drinking water basin: a case study. Environ. Sci. Technol. 47:574-583.

Bright DI, Walsby AE, 2000. The daily integral of growth by Planktothrix rubescens calculated from growth rate in culture and irradiance in Lake Zurich. New Phytol. 146:301-316.

Carraro E, Guyennon N, Hamilton D, Valsecchi L, Manfredi E, Viviano G, Salerno F, Tartari G, Copetti D, 2012. Coupling high-resolution measurements to a three-dimensional lake model to assess the spatial and temporal dynamics of the cyanobacterium Planktothrix rubescens in a medium-sized lake. Hydrobiologia 698:77-95.

Cerasino L, Salmaso N, 2012. Diversity and distribution of cyanobacterial toxins in the Italian subalpine lacustrine district. Oceanol. Hydrobiol. St. 41:54-63.

Cerasino L, Shams S, Boscaini A, Salmaso N, 2016. Multiannual trend of microcystin production in the toxic cyanobacterium Planktothrix rubescens in Lake Garda (Italy). Chem. Ecol. 32:492-506.

Clegg MR, Maberly SC, Jones RI, 2003. Behavioural responses of freshwater phytoplanktonic flagellates to a temperature gradient. Eur. J. Phycol. 38:195-203.

Clegg MR, Maberly SC, Jones RI, 2004. Chemosensory behavioural response of freshwater phytoplanktonic flagellates. Plant. Cell. Environ. 27:123-135.

Clegg MR, Maberly SC, Jones RI, 2007. Behavioral response as a predictor of seasonal depth distribution and vertical niche separation in freshwater phytoplanktonic flagellates. Limnol. Oceanogr. 52:441-455.

Crawley MJ, 2005. Statistics. An introduction using R. J. Wiley \& Sons, Chichester.

Cuypers Y, Vincon-Leite B, Groleau A, Tassin B, Humbert JF, 2011. Impact of internal waves on the spatial distribution of Planktothrix rubescens (cyanobacteria) in an alpine lake. ISME J. 5:580-589.

D’Alelio D, Gandolfi A, Boscaini A, Flaim G, Tolotti M, Salmaso N, 2011. Planktothrix populations in subalpine lakes: selection for strains with strong gas vesicles as a function of lake depth, morphometry and circulation. Freshwater Biol. 56:1481-1493. 
D’Alelio D, Salmaso N, Gandolfi A, 2013. Frequent recombination shapes the epidemic population structure of Planktothrix (Cyanoprokaryota) in Italian subalpine lakes. J. Phycol. 49:1107-1117.

Di Gregorio FN, Bogialli S, Ferretti E, Lucentini L, 2017. First evidence of MC-HtyR associated to a Plankthothrix rubescens blooming in an Italian lake based on a LC-MS method for routinely analysis of twelve microcystins in freshwaters. Microchem. J. 130:329-335.

Dokulil MT, Teubner K, 2012. Deep living Planktothrix rubescens modulated by environmental constraints and climate forcing. Hydrobiologia 698:29-46.

Ernst B, Hitzfeld B, Dietrich D, 2001. Presence of Planktothrix sp. and cyanobacterial toxins in Lake Ammersee, Germany and their impact on whitefish (Coregonus lavaretus L.). Environ. Toxicol. 16:483-488.

Feuillade J, Feuillade M, Blanc P, 1990. Alkaline phosphatase activity fluctuations and associated factors in a eutrophic lake dominated by Oscillatoria rubescens. Hydrobiologia 207:233-240.

Fietz S, Kobanova G, Izmest'eva L, Nicklisch A, 2005. Regional, vertical and seasonal distribution of phytoplankton and photosynthetic pigments in Lake Baikal. J. Plankton Res. 27:793-810.

Fleming LE, Backer L, Rowan A, 2002. The epidemiology of human illnesses associated with harmful algal blooms, $p$. 363-381. In: D. Baden and D. Adams (eds.), Neurotoxicology handbook. 1. Humana Press, Totowa.

Gaget V, Welker M, Rippka R, de Marsac NT, 2015. A polyphasic approach leading to the revision of the genus Planktothrix (Cyanobacteria) and its type species, P. agardhii, and proposal for integrating the emended valid botanical taxa, as well as three new species, Planktothrix paucivesiculata sp. nov. IC. Syst. Appl. Microbiology 38:141-58.

Garneau ME, Posch T, Hitz G, Pomerleau F, Pradalier C, Siegwart R, Pernthaler J, 2013. Short-term displacement of Planktothrix rubescens (cyanobacteria) in a pre-alpine lake observed using an autonomous sampling platform. Limnol. Oceanogr. 58:1892-1906.

George D, 1981. The spatial distribution of nutrients in the South Basin of Windermere. Freshwater Biol. 11:405-424.

George D, Edwards R, 1976. The effect of wind on the distribution of chlorophyll a and crustacean plankton in a shallow eutrophic reservoir. J. Appl. Ecol. 13:667-690.

George D, Heaney S, 1978. Factors influencing the spatial distribution of phytoplankton in a small productive lake. J. Ecol. 66:133-155.

Gregor J, Geriš R, Maršálek B, Heteša J, Marvan P, 2005. In situ quantification of phytoplankton in reservoirs using a submersible spectrofluorometer. Hydrobiologia 548:141-151.

Guellati FZ, Touati H, Tambosco K, Quiblier C, Humbert JF, Bensouilah M, 2017. Unusual cohabitation and competition between Planktothrix rubescens and Microcystis sp. (cyanobacteria) in a subtropical reservoir (Hammam Debagh) located in Algeria. PloS One 12:e0183540.

Halstvedt CB, Rohrlack T, Andersen T, Skulberg O, Edvardsen B, 2007. Seasonal dynamics and depth distribution of Planktothrix spp. in Lake Steinsfjorden (Norway) related to environmental factors. J. Plankton Res. 29:471-482.

Hamilton DP, O'Brien KR, Burford MA, Brookes JD, McBride
CG, 2010. Vertical distributions of chlorophyll in deep, warm monomictic lakes. Aquat. Sci. 72:295-307.

Hillmer I, van Reenen P, Imberger J, Zohary T, 2008. Phytoplankton patchiness and their role in the modelled productivity of a large, seasonally stratified lake. Ecol. Model. 218:49-59.

Hitzfeld BC, Höger SJ, Dietrich DR, 2000. Cyanobacterial toxins: removal during drinking water treatment, and human risk assessment. Environ. Health Persp. 108:113-122.

Hoeger SJ, Hitzfeld BC, Dietrich DR, 2005. Occurrence and elimination of cyanobacterial toxins in drinking water treatment plants. Toxicol. Appl. Pharm. 203:231-242.

Humbert JF, Törökné A, 2017. New tools for the monitoring of cyanobacteria in freshwater ecosystems, p. 84-88. In: J. Meriluoto, L. Spoof and G.A. Codd (eds.), Handbook on cyanobacterial monitoring and cyanotoxin analysis. J. Wiley \& Sons, Chichester.

Jacquet S, Briand JF, Leboulanger C, Avois-Jacquet C, Oberhaus L, Tassin B, Vincon-Leite B, Paolini G, Druart JC, Anneville O, Humbert JF, 2005. The proliferation of the toxic cyanobacterium Planktothrix rubescens following restoration of the largest natural French lake (Lac du Bourget). Harmful Algae 4:651-672.

Jacquet S, Kerimoglu O, Rimet F, Paolini G, Anneville O, 2014. Cyanobacterial bloom termination: the disappearance of Planktothrix rubescens from Lake Bourget (France) after restoration. Freshwater Biol. 59:2472-2487.

Jeppesen E, Søndergaard M, Jensen JP, Havens KE, Anneville O, Carvalho L, Coveney MF, Deneke R, Dokulil MT, Foy BOB, Gerdeaux D, Hampton SE, Hilt S, Kangur K, Kohler J, Lammens EHHR, Lauridsen TL, Manca M, Miracle MR, Moss B, Noges P, Persson G, Phillips G, Portielje ROB, Romo S, Schelske CL, Straile D, Tatrai I, Willen EVA, Winder M, 2005. Lake responses to reduced nutrient loading - an analysis of contemporary long-term data from 35 case studies. Freshwater Biol. 50:1747-1771.

Joannin S, Vanniere B, Galop D, Peyron O, Haas JN, Gilli A, Chapron E, Wirth S.B, Anselmetti F, Desmet M, Magny M, 2013. Climate and vegetation changes during the Lateglacial and early-middle Holocene at Lake Ledro (southern Alps, Italy). Clim. Past 9:913-933.

Kirk JTO, 2011. Light and photosynthesis in aquatic ecosystems, 3. Cambridge University Press, Cambridge.

Klausmeier CA, Litchman E, 2001. Algal games: The vertical distribution of phytoplankton in poorly mixed water columns. Limnol. Oceanogr. 46:1998-2007.

Köker L, Akçaalan R, Albay M, Neilan BA, 2017. Molecular detection of hepatotoxic cyanobacteria in inland water bodies of the Marmara Region, Turkey. Adv. Oceanogr. Limn. 8:52-60.

Komárek J, Anagnostidis K, 2005. Cyanoprokaryota. part 2: Oscillatoriales. Süßwasserflora von Mitteleuropa, Band 19/2. Spektrum Akademische Verlag, Heidelberg.

Kring SA, Figary SE, Boyer GL, Watson SB, Twiss MR, 2014. Rapid in situ measures of phytoplankton communities using the bbe FluoroProbe: evaluation of spectral calibration, instrument intercompatibility, and performance range. Can. J. Fish. Aquat. Sci. 71:1087-1095.

Kurmayer R, Gumpenberger M, 2006. Diversity of microcystin genotypes among populations of the filamentous cyanobac- 
teria Planktothrix rubescens and Planktothrix agardhii. Mol. Ecol. 15:3849-3861.

Kurmayer R, Blom JF, Deng L, Pernthaler J, 2015. Integrating phylogeny, geographic niche partitioning and secondary metabolite synthesis in bloom-forming Planktothrix. ISME J. 9:909-921.

Lampert W, Sommer U, 2007. Limnoecology - The ecology of lakes and streams. Oxford University Press, London.

Leboulanger C, Dorigo U, Jacquet S, Le Berre B, Paolini G, Humbert JF, 2002. Application of a submersible spectrofluorometer for rapid monitoring of freshwater cyanobacterial blooms: a case study. Aquat. Microb. Ecol. 30: 83-89.

Legnani E, Copetti D, Oggioni A, Tartari G, Palumbo MT, Morabito G, 2005. Planktothrix rubescens' seasonal dynamics and vertical distribution in Lake Pusiano (North Italy). J. Limnol. 64:61-73.

Longhi ML, Beisner BE, 2009. Environmental factors controlling the vertical distribution of phytoplankton in lakes. J. Plankton Res. 31:1195-1207.

Magny M, Galop D, Bellintani P, Desmet M, Didier J, Haas JN, Martinelli N, Pedrotti A, Scandolari R, Stock, A, Vanniere B, 2009. Late-Holocene climatic variability south of the Alps as recorded by lake-level fluctuations at Lake Ledro, Trentino, Italy. Holocene 19, 575-589.

Manganelli M, Viaggiu E, Barone R, Buzzi F, Caviglia F, Congestri R, Copetti D, De Angelis R, Godeas F, Guzzella L, Masala E, Naselli-Flores L, Salmaso N, Scardala S, 2014. National situation: water bodies affected by toxic cyanobacteria (in Italian). Rapporti ISTISAN - National Health Institute 14/20:116-143.

Meriluoto J, Blaha L, Bojadzija G, Bormans M, Brient L, Codd GA, Drobac D, Faassen EJ, Fastner J, Hiskia A, Ibelings BW, Kaloudis T, Kokocinski M, Kurmayer R, Pantelić D, Quesada A, Salmaso N, Tokodi N, Triantis TM, Visser PM, Svirčev Z, 2017. Toxic cyanobacteria and cyanotoxins in European waters - recent progress achieved through the CYANOCOST Action and challenges for further research. Adv. Oceanogr. Limnol. 8:6429.

Messineo V, Mattei D, Melchiorre S, Salvatore G, Bogialli S, Salzano R, Mazza R, Capelli G, Bruno M, 2006. Microcystin diversity in a Planktothrix rubescens population from Lake Albano (Central Italy). Toxicon 48:160-174.

Metcalf JS, Codd GA, 2012. Cyanotoxins, p. 651-675. In: BA Whitton (ed.), Ecology of cyanobacteria II: Their diversity in space and time. Springer, Dordrecht.

Micheletti S, Schanz F, Walsby AE, 1998. The daily integral of photosynthesis by Planktothrix rubescens during summer stratification and autumnal mixing in Lake Zürich. New Phytol. 139:233-246.

Milan M, Bindler R, Tolotti M, 2016. Combining sediment Cladocera remains and geochemistry to reveal the role of a large catchment in driving changes in a small subalpine lake (lake Ledro, N-Italy). Adv. Oceanogr. Limnol. 7:6399.

Moreno-Ostos E, Cruz-Pizarro L, Basanta- Alvés A, Escot C, George D, 2006. Algae in the motion: spatial distribution of phytoplankton in thermally stratified reservoirs. Limnetica 25:205-217.

Moreno-Ostos E, Cruz-Pizarro L, Basanta A, George DG, 2009. Spatial heterogeneity of cyanobacteria and diatoms in a ther- mally stratified canyon-shaped reservoir. Int. Rev. Hydrobiol. 94:245-257.

Naselli-Flores L, Barone R, 2000. Phytoplankton dynamics and structure: a comparative analysis in natural and man-made water bodies of different trophic state. Hydrobiologia 438:65-74.

Oberhaus L, Briand J, Leboulanger C, Jacquet S, Humbert J, 2007. Comparative effects of the quality and quantity of light and temperature on the growth of Planktothrix agardhii and P. rubescens. J. Phycol. 43:1191-1199.

Oliver RL, Ganf GG, 2002. Freshwater blooms, p. 149-194. In: B.A. Whitton and M. Potts (eds.), The ecology of cyanobacteria, Kluwer Academic Publishers, Dortrecht.

Oliver RL, Hamilton DP, Brookes JD, Ganf GG, 2012. Physiology, blooms and prediction of planktonic cyanobacteria, p. 155194. In: Ecology of cyanobacteria II. Springer, Dordrecht.

Padisák J, Hajnal É, Krienitz L, Lakner J, Üveges V, 2010. Rarity, ecological memory, rate of floral change in phytoplankton - and the mystery of the Red Cock. Hydrobiologia 653:45-64.

Paerl HW, 1988. Growth and reproductive strategies of freshwater blue-green algae (Cyanobacteria), p. 261-315. In: C.D. Sandgren (ed.), Growth and reproductive strategies of freshwater phytoplankton. Cambridge University Press, Cambridge.

Regel RH, Brookes JD, Ganf GG, 2004. Vertical migration, entrainment and photosynthesis of the freshwater dinoflagellate Peridinium cinctum in a shallow urban lake. J. Plankton Res. 26:143-157.

Reynolds CS, 2006. The ecology of phytoplankton, Ecology. Cambridge University Press.

Reynolds CS, Huszar V, Kruk C, Naselli-Flores L, Melo S, 2002. Towards a functional classification of the freshwater phytoplankton. J. Plankton Res. 24:417-428.

Rhiel E, Hädert DP, Wehrmeyer W, 1988. Photo-orientation in a freshwater Cryptomonas species. J. Photoch. Photobio. B 2:123-132.

Rott E, Salmaso N, Hoehn E, 2007. Quality control of Utermohlbased phytoplankton counting and biovolume estimates - an easy task or a Gordian knot? Hydrobiologia 578:141-146.

Salcher MM, Pernthaler J, Frater N, Posch T, 2011. Vertical and longitudinal distribution patterns of different bacterioplankton populations in a canyon-shaped, deep prealpine lake. Limnol. Oceanogr. 56:2027-2039.

Salmaso N, Morabito G, Buzzi F, Garibaldi L, Simona M, Mosello R, 2006. Phytoplankton as an indicator of the water quality of the deep lakes south of the Alps. Hydrobiologia 563:167-187.

Salmaso N, Padisák J, 2007. Morpho-Functional Groups and phytoplankton development in two deep lakes (Lake Garda, Italy and Lake Stechlin, Germany). Hydrobiologia 578:97-112.

Salmaso N, Boscaini A, Shams S, Cerasino L, 2013. Strict coupling between the development of Planktothrix rubescens and microcystin content in two nearby lakes south of the Alps (lakes Garda and Ledro). Ann. Limnol.-Int. J. Lim. 49:309-318.

Salmaso N, Copetti D, Cerasino L, Shams S, Capelli C, Boscaini A, Valsecchi L, Pozzoni F, Guzzella L, 2014a. Variability of microcystin cell quota in metapopulations of Planktothrix rubescens: Causes and implications for water management. Toxicon 90:82-96. 
Salmaso N, Copetti D, Guzzella L, Manganelli M, Masala E, Naselli-Flores L, 2014b. [Factors controlling the development of toxic cyanobacterial blooms with particular reference to eutrophication and climate change].[Article in Italian]. Rapporti ISTISAN - National Health Institute 14/20:5-36.

Salmaso N, Cerasino L, Boscaini A, Capelli C, 2016. Planktic Tychonema (Cyanobacteria) in the large lakes south of the Alps: phylogenetic assessment and toxigenic potential. FEMS Microbiol. Ecol. 92:pii:fiw155.

Salmaso N, Bernard C, Humbert JF, Akçaalan R, Albay M, Ballot A, Catherine A, Fastner J, Häggqvist K, Horecka M, Izydorczyk K, Köker L, Komárek J, Maloufi S, Mankiewicz-Boczek J, Metcalf JS, Quesada A, Quiblier C, Yéprémian C, 2017. Basic guide to detection and monitoring of potentially toxic cyanobacteria, p. 46-69. In: J. Meriluoto, L. Spoof and G.A. Codd (eds.), Handbook on cyanobacterial monitoring and cyanotoxin analysis. J. Wiley \& Sons, Chichester.

Salonen K, Sarvala J, Järvinen M, Langenberg V, Nuottajärvi M, Vuorio K, Chitamwebwa D, 1999. Phytoplankton in Lake Tanganyika - vertical and horizontal distribution of in vivo fluorescence. Hydrobiologia 407:89-103.

Santo MA, Toffolon M, Zanier G, Giovannini L, Armenio V, 2017. Large eddy simulation (LES) of wind-driven circulation in a peri-alpine lake: detection of turbulent structures and implications of a complex surrounding orography. J. Geophys. Res-Ocean. 122:4704-4722.

Selmeczy GB, Tapolczai K, Casper P, Krienitz L, Padisák J, 2016. Spatial-and niche segregation of DCM-forming cyanobacteria in Lake Stechlin (Germany). Hydrobiologia 764:229-240.

Serra T, Vidal J, Casamitjana X, Soler M, Colomer J, 2007. The role of surface vertical mixing in phytoplankton distribution in a stratified reservoir. Limnol. Oceanogr. 52:620-634.

Shams S, Cerasino L, Salmaso N, Dietrich DR, 2014. Experimental models of microcystin accumulation in Daphnia magna grazing on Planktothrix rubescens: Implications for water management. Aquat. Toxicol. 148:9-15.

Simmonds B, Wood S, Özkundakci D, Hamilton D, 2015. Phytoplankton succession and the formation of a deep chlorophyll maximum in a hypertrophic volcanic lake. Hydrobiologia 745:297-312.

Simonneau A, Chapron E, Vannière B, Wirth SB, Gilli A, Di Giovanni C, Anselmetti FS, Desmet M, Magny M, 2013. Mass-movement and flood induced deposits in Lake Ledro, southern Alps, Italy: implications for Holocene palaeohydrology and natural hazards. Clim. Past 9:825-840.

Sotton B, Guillard J, Anneville O, Maréchal M, Savichtcheva O, Domaizon I, 2014. Trophic transfer of microcystins through the lake pelagic food web: Evidence for the role of zooplankton as a vector in fish contamination. Sci. Total Environ. 466:152-163.

Suda S, Watanabe MM, Otsuka S, Mahakahant A, Yongmanitchai W, Nopartnaraporn N, Liu Y, Day JG, 2002. Taxonomic revision of water-bloom-forming species of oscillatorioid cyanobacteria. Int. J Syst. Evol.Micr. 52:1577-1595.

Sukenik A, Quesada A, Salmaso N, 2015. Global expansion of toxic and non-toxic cyanobacteria: effect on ecosystem functioning. Biodivers. Conserv. 24:889-908.

Svircev Z, Krstic S, Miladinov-Mikov M, Baltic V, Vidovic M, 2009. Freshwater cyanobacterial blooms and primary liver cancer epidemiological studies in Serbia. J. Environ. Sci. Heal. C 27:36-55.

Ueno Y, Nagata S, Tsutsumi T, Hasegawa A, Watanabe MF, Park HD, Chen GC, Yu SH, 1996. Detection of microcystins, a blue-green algal hepatotoxin, in drinking water sampled in Haimen and Fusui, endemic areas of primary liver cancer in China, by highly sensitive immunoassay. Carcinogenesis 17:1317-1321.

Vanniere B, Magny M, Joannin S, Simonneau A, Wirth SB, Hamann Y, Chapron E, Gilli A, Desmet M, Anselmetti FS, 2013. Orbital changes, variation in solar activity and increased anthropogenic activities: controls on the Holocene flood frequency in the Lake Ledro area, Northern Italy. Clim. Past 9:1193-1209.

Vareli K, Briasoulis E, Pilidis G, Sainis I, 2009. Molecular confirmation of Planktothrix rubescens as the cause of intense, microcystin - Synthesizing cyanobacterial bloom in Lake Ziros, Greece. Harmful Algae 8:447-453.

Vasas G, Farkas O, Borics G, Felföldi T, Sramkó G, Batta G, Bácsi I, Gonda S, 2013. Appearance of Planktothrix rubescens bloom with [D-Asp3, Mdha7] MC-RR in gravel pit pond of a shallow lake-dominated area. Toxins 5:2434-2455.

Vuillermoz E, Legnani E, Copetti D, Tartari G, 2006. Thirtyyears of Lake Pusiano (North Italy) evolution. Verh. Internat.Verein. Limnol. 29:2009-2014.

Walsby AE, 2005. Stratification by cyanobacteria in lakes: a dynamic buoyancy model indicates size limitations met by Planktothrix rubescens filaments. New Phytol. 168:365-376.

Walsby AE, Schanz F, 2002. Light-dependent growth rate determines changes in the population of Planktothrix rubescens over the annual cycle in Lake Zurich, Switzerland. New Phytol. 154:671-687.

Walsby AE, Ng G, Dunn C, Davis PA, 2004. Comparison of the depth where Planktothrix rubescens stratifies and the depth where the daily insolation supports its neutral buoyancy. New Phytol. 162:133-145.

Walsby AE, Schanz F, Schmid M, 2006. The Burgundy-blood phenomenon: a model of buoyancy change explains autumnal waterblooms by Planktothrix rubescens in Lake Zurich. New Phytol. 169:109-122.

Whittington J, Sherman B, Green D, Oliver RL, 2000. Growth of Ceratium hirundinella in a subtropical Australian reservoir: the role of vertical migration. J. Plankton Res. 22:1025-1045.

Whitton BA, Potts M, 2000. The ecology of cyanobacteria: Their diversity in time and space. Kluwer Academic Publishers, Dordrecht.

Wilmotte A, Laughinghouse HDI, Capelli C, Rippka R, Salmaso N, 2017. Taxonomic identification of cyanobacteria by a polyphasic approach, p. 79-119. In: R. Kurmayer, K. Sivonen, A.Wilmotte and N. Salmaso (eds.), Molecular Tools for the detection and quantification of toxigenic cyanobacteria. J. Wiley \& Sons, Chichester.

Wolf HU, Frank C, 2002. Toxicity assessment of cyanobacterial toxin mixtures. Environ. Toxicol. 17:395-399.

Zhou L, Yu H, Chen K, 2002. Relationship between microcystin in drinking water and colorectal cancer. Biomed. Environ. Sci. 15:166-171.

Zotina T, Koster O, Juttner F, 2003. Photoheterotrophy and lightdependent uptake of organic and organic nitrogenous compounds by Planktothrix rubescens under low irradiance. Freshwater Biol. 48:1859-1872. 